\title{
Han Fei's Enlightened Ruler
}

\section{Alejandro Bárcenas}

In this essay I will revise, based on the notion of the 'enlightened ruler' or mingzhu and his critique of the literati of his time, the common belief that Han Fei was an amoralist and an advocate of tyranny. Instead, I will argue that his writings are dedicated to advising those who ought to rule in order to achieve the goal of a peaceful and stable society framed by laws in accordance with the dao.

The sage who makes the laws effective in the state is always acting contrary to the prevailing opinions of the age, but is in accord with the dao and excellence. ${ }^{1}$

Han Feizi, XIV

The interpretative literature on Han Fei has traditionally focused on criticizing his political philosophy, generally accusing him of being the 'staunchest possible supported of absolute power' (Pines, 2013, p. 84). As a result, little to no effort has been placed in trying to coherently construct his own philosophical perspective. For instance, considering how much Han Fei has been judged for allegedly giving 'evil advice' to rulers, there is surprisingly little effort dedicated to studying how he conceived the possibility of an ideal monarch. ${ }^{2}$ Among other issues, Han Fei's criticism of the Confucian literati of his time has proven to be a significant factor in the lack of interest that interpreters tend to show with regard to the Legalist's political vision. ${ }^{3}$ Because of the dominance played by Confucianism in China, beginning early in the Han dynasty under the rule of Han Wudi (漢武帝), ${ }^{4}$ his legacy has paid a lofty price: his ideas have been subject to considerable disdain and, in the 'best' cases, consigned to oblivion. When it comes to the research done in Western languages, it seems that the lack of interest in Han Fei's politics becomes even more glaring with regard to his notion of the ideal ruler. Han Fei used a specific term to refer to such a ruler-no doubt a term of great significance to him since it appears in the text on over 90 occasions. Han Fei called his ideal ruler mingzhu (明 主), the 'enlightened ruler'. 5

In this essay I will revise, based on his notion of the 'enlightened ruler', the extent to which Han Fei is supposed to have justified the use of power in accordance to the idiosyncratic and manipulative will of the ruler or turned power into an end in itself.

Correspondence to: Alejandro Bárcenas, Philosophy Department, Texas State University, San Marcos, TX 78666, USA. Email: ab75@txstate.edu 
I will also ponder if it is really the case that for Han Fei, 'his treatment [of the ruler] is frequently driven by political ambitions rather than philosophical reflection' (Lai, 2008, p. 173). In addition, I will call into question the idea that what Han Fei wrote is just a 'behavioral science' (Schwartz, 1985, p. 321) or, even worse, that Han Fei 'professed to have no use for morality whatsoever' (Watson, 2003, p. 7) and consequently wrote 'an amoral science of statecraft' (Graham, 1989, p. 267). ${ }^{6}$ Those appreciations, instead of clarifying the intentions of his philosophical project, seem to have led a number of interpreters to characterize Han Fei as an apologist of tyranny. $^{7}$

\section{Learning from the Past}

In order to understand the intellectual environment in which Han Fei developed his idea of the 'enlightened ruler', I will begin by expounding in general terms the role of the past as a model during the third century BCE in China. Han Fei's writings seem to transmit to the reader the sense that the issue of the meaning of the past was one of great contention during his time (Goldin, 2008). However, this issue was not by any means a new one: some two centuries earlier it had already become for Confucius one of the pillars of his philosophy.

Confucius was particularly interested in the prosperous time of the Zhou dynasty that began about the twelfth century BCE and lasted until about the eight century BCE, when it lost its centralized government (Pines, 2002a, p. 3; Watson, 2003, p. 5). Confucius, who lived about 250 years after the destruction of the central capital of the Western Zhou, considered the Zhou dynasty superior to other previous dynasties. ${ }^{8}$ His repeated praise of the Zhou in the Analects guided his disciples in their attempt to follow the master and apply the wisdom that gave prosperity and integrity to several generations of rulers. With time a certain group of 'officials' or 'literati', known as shi (士), who filled the middle and lower rank of the civil government became known as $r u(\text { 儒 })^{9}$ for their concern in transmitting the culture of the Zhou. During the following years, mastery of the Zhou rituals and texts became a valuable qualification for public office.

Although after the time of Confucius this group of literati became loosely associated with Confucianism, ${ }^{10}$ recent studies on the subject suggest that by the time of Han Fei the $r u$ included a quite broad spectrum of people, from experts in social life, discourse and religious rituals to professional artists and advisors. ${ }^{11}$ In general, it seems that at least a significant number of them became quite derailed from the original pursuit of becoming accomplished (ren 仁) to the extent that, in retrospect, they could hardly be considered Confucian at all. For instance, as Cho-yun Hsu explains in his book Ancient China in Transition, they had an attitude of strict respect for the past in which 'tradition determined the criteria for propriety' (Hsu, 1965, p. 154) and innovation and novelty were indeed seldom acclaimed' (Hsu, 1965, p. 154). This attitude did not have any of the openness advocated by Confucius himself (Ames, 1994, p. 3) and, Hsu argues, it seemed to be inspired at least in part by the literati's literal reading and 
utmost devotion to bronze inscriptions and certain stories from texts such as the Book of Songs (Hsu, 1965, pp. 22-23). ${ }^{12}$ Han Fei showed particular concern with the damaging effects to society brought by their corrupt personas and by their stubborn repetition of past formulas since the actual applicability of their skills appeared to have nothing to do with the pressing issues of the time. ${ }^{13}$

According to Kung-chuan Hsiao's suggestion, the attitude of those in that period who 'observed the vast and unprecedented transformations underway in society and who tried to devise positive responses during this time' (Hsiao, 1979, p. 378) can be, in broad terms, divided into two groups. The first group-formed by scholars of diverse tendencies-regretted the fall of the feudal order of the Zhou and wished to rescue or recreate it in some form or another. The other group, to which Han Fei seemed to belong, 'observed that the feudal order was not worth saving and was already ready to let it wither away' (Hsiao, 1979, p. 378). But the issue at hand seems to be more complex than Hsiao's simple, but useful, categorization. The separation into two completely different groups is not entirely accurate. First, it is important to realize that for Han Fei not everything from the time of the Zhou needed to vanish. As the Legalist philosopher explained in chapter XVIII:

Whether or not ancient standards should be changed, whether or not established standards should be removed, all depends upon the question whether or not they are still useful for the present. ${ }^{14}$

As this passage shows, it is possible to argue that, for Han Fei, the Zhou legal foundation did not need to disappear entirely, but rather become actualized according to the current circumstances. In effect it is quite possible, as Hsiao also argued, that Han Fei's entire Legalist philosophy might have been inspired by a whole body of thought concerned with governing by laws that had its origins during the Zhou period (Hsiao, 1979, pp. 376-377).

By the late third century BCE it seemed from Han Fei's point of view as if the $r u$, despite their best efforts, had failed to find or educate those people capable of realizing a society inspired by the Zhou institutions. Han Fei felt that the literati had plenty of opportunities to apply their ideas and address the social and political problems of the time. His assessment was that, not only had they failed, but also time appeared to be running out for civilized society before violence and chaos became completely unmanageable. There is a sense of urgency in Han Fei that seems to leave him without any patience to concede more time to the scholars who had become a common sight in the courts of the states that comprised China at the time.

In this regard, Han Fei's ideas originated, to a great extent, as a response to the failure of the literati to apply the model of the Zhou society and of ancient kings to the political circumstances of the period. While the institutions and the moral fabric of the society continued to decay, it appears that the literati succumbed to the mistake of turning the pursuit of the "traditional Zhou cultural forms ${ }^{15}$ into an end in itself. Han Fei was critical of this inflexible stance because it had become stagnant and, thus incapable of adapting to the always-changing circumstances. 
Only those who have no understanding of effective government always say 'do not change traditions, do not change what is established'. Change or no change, the sage does not listen [to those with no understanding], for he aims only at the rectification of government. ${ }^{16}$

In order to further clarify his criticism of those whom he considered to have 'no understanding' of how to rectify government, because they had shown themselves incapable of adapting to the political needs of the day, Han Fei tells a story about a farmer who abandons his everyday duties, wishing instead that an unusual moment of luck could strike twice.

A man from Song was plowing his field, in which there was a stump. A rabbit ran through the field and crashed into the stump, breaking its neck and dying. From then on, the man laid aside his plow and kept watch over the stump, hoping that he would get another rabbit. But he got no more rabbits in this way, and was the laughingstock of Song. If one desires to use the government of the ancient rulers to effectively govern ( $z h i$ 治) the people of today, one would be doing the same as the man from Song who watched the stump. ${ }^{17}$

Taking into consideration the intellectual background, the point of the passage is quite clear. Han Fei used a metaphorical critique of the literati's attitude of the time to mock those who naively thought that history could repeat itself in the same exact way. For a careful student of the past, such as Han Fei, the thought that an event could happen in the exact same way in two different periods was a sign of unfamiliarity with the processual nature of historical events. Historical records showed that just because an event occurred once in history, it did not mean that it could do so again in the same way. In other words, there was no chance that a prosperous dynasty (like the Zhou) could reemerge spontaneously through the blind replication of its institutions and customs. So, if the literati thought that history behaved as a series of events designed by luck, they were leading society into disaster.

Like the man from Song, for Han Fei, the literati of the time were just preaching a blind repetition of the past, and were not concerned with a careful investigation of the social and political situation at hand. They had learned a series of set formulas and simply did not know how to adapt and act intelligently according to the changing circumstances.

In fact, in another passage Han Fei seems to remind the scholars of his time that they have forgotten a key teaching from their self-proclaimed master: the intrinsic mutability of everything in the world and the need to be in harmony with it. It seemed to Han Fei as if they had forgotten that dao 'denotes the active project of "road building"' (Ames \& Rosemont, 1998, p. 45) ${ }^{18}$ and not traveling a road made by others. This means that ideas, like everything else, need to develop if they are to be effectively applied in a world of 'silent transformations'. ${ }^{19}$ Han Fei seems to remind the scholars that such notions-those that are effectively applied-need to be in harmony with the $d a o$, but when they are alienated from reality, because its historically defined content is not comprehended, they only lead to chaos. In chapter LI, he wrote: 
All under the heavens affirm the dao of filial piety (xiao 孝), fraternal respect ( $t i$ 悌), loyalty (zhong 忠), and obedience (shun 順) but none of them understand to probe into it and to practice it critically; therefore, all under the heavens is in chaos. ${ }^{20}$

Given the desperate times of the Warring States period, failure to adapt was more than just a simple and harmless blunder. The actual situation was becoming more desperate by the day, as society itself faced utter disintegration. The literati continued to show that they lacked the capability to reflect and consider the foundational notions of a society and kept hoping for a return of the Zhou order. Their advice had become repetitive and lacked the necessary insight to conform to the changing circumstances; hence, it had become clear for Han Fei that the literati had lost touch with the political needs of their time.

Furthermore, Han Fei observed in another passage that they had become afraid of change and continued to mindlessly apply failed policies that, in the best of cases, did little more than serve the immediate satisfaction of the people and their rulers. However, one could understand why the literati would prefer to cling to one set of standards with considerable devotion when the general feeling of the time was that 'the standard of true and false ceased to exist, so that the permissible and the nonpermissible fluctuated from day to day' (Hsiao, 1979, p. 369). In this regard, they felt as the guardians and providers of stability for a time characterized by contingency. As Hsü explains, they were hoping that if time had stood still the upper elements of the structure would have retained their conviction of divinely granted superiority, and the lower elements would have had to accept their lot ungrudgingly' (Hsu, 1965, pp. 2223). In effect, it seems that they got so accustomed to proposing principles and institutions already familiar to them that they behaved as if they did not care about the consequences of applying them to the present, in spite of the fact that the historical circumstances had changed.

Those who are against changing the ancient traditions do so because they dread affecting the stability of the people. Those who do not change the ancient traditions are following on in the footsteps of chaos. Those who only satisfy the people's feelings encourage unrestrained vices. Obtuse people do not understand what leads to chaos, and if the ruler is weak and cannot implement change, this leads to the failure of the effective government (治 $z h i$ ). Enlightened rulers are able to understand the conditions of effective government. Their constancy is such that they are able to implement an effective government even if it goes against the feelings of the people. $^{21}$

The harsh reality of the third century BCE was that the ancient institutions and therefore their social customs ( $l i$ 禮) continued to disintegrate in spite of the scholars' best efforts. For Han Fei, if a new age of prosperity was ever to return to the land, it needed to be formulated not just as a state of things that perhaps could occur in the future, but in a way that could be applied in the present conditions of war and disorder.

Even if a society based on Confucius' ideas was possible, the fact was that it required time to grow and develop, but time had passed by and little had changed. 
Two centuries before Han Fei's era, even Confucius himself admitted that, it would take one hundred years if truly efficacious people (shanren 善人) were in charge of government to be able to overcome violence and dispense with killing altogether. ${ }^{22}$ Han Fei realized that even after all this time, 'among one hundred people there is not even one who would practice a conduct of high level. ${ }^{, 23}$ Hence, there was no reason for a society to continue following a path that only led to failure and, from his point of view, would continued to do so. The nature of the whole political enterprise needed to shift.

During those 200 years between the death of Confucius and Han Fei's time, the collapse of the Zhou feudalism gave way to a new set of powerful local feudal lords who did not belong to the ancient hereditary noble families. Those new feudal lords began an aggressive campaign of war and annexation among neighboring states. Among those states, the land of Qin accumulated more military might than any other state and by the third century BCE Han Fei's home territory, the state of Han (韓) as well as many others, faced utter destruction. In other words, neither Han Fei nor the people from his land could afford to wait 'one hundred years' to achieve peace and prosperity.

In this regard, it is quite possible that Han Fei felt the same way toward the ideal of a Confucian society as Aristotle did toward Plato's inability to make the 'best city'

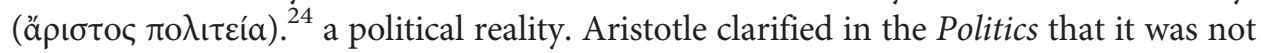
enough to be able to formulate in theory the best society, but not know how to achieve its realization:

For the best city is often unattainable, and therefore the true legislator and statesman ought to be acquainted, not only with what is best in the abstract, but also with that which is best relative to circumstances. ${ }^{25}$

\section{Rhetoric and Private Interests (si 私)}

The failure of the $r u$ to make their view of society a reality was manifested by the advice given by them to the rulers and their courts. Han Fei saw the literati of his time as consumed by the pursuit of their private interests ( $s i$ 私). As a consequence, they were showing a pervasive disregard for any formulation of standards that could limit their self-centered enterprise. 'Most ministers of today defend their private ( $s i$ 私) ideas,' Han Fei complained, 'they do not follow the law, regard wickedness as wisdom and establish their own interests beyond the boundary of the law. To restrict such conduct, is the dao of the ruler. ${ }^{26}$

In time, the pursuit of private interests made the literati turn their backs on the people they were supposed to help according to the teachings of Confucius, and, in addition, made them disloyal to the government they were expected to serve. A consequence of the private pursuits of the literati, François Jullien writes, was that 'individual knowledge is doomed to remain fragmentary, incomplete and therefore tainted by subjectivity' (Jullien, 1992, pp. 45-46). As Jullien explains, the literati's selfcenteredness made them 'fragmentary' and, therefore, alienated from the overall good 